Karcı, S. ve Karakoç, M. (2021). "Taşrada Farklı Kadınlık Halleri: Kadın Mali Müşavirler Özelinde Bir Değerlendirme”, Eskişehir Osmangazi Üniversitesi iiBF Dergisi, 16(3), 594 -614.

Doi: 10.17153/oguiibf.934323

Başvuru: 07.05.2021 Kabul: 29.05.2021

Araştırma Makalesi/Research Article

\title{
Taşrada Farklı Kadınlık Halleri: Kadın Mali Müşavirler Özelinde Bir Değerlendirme
}

\begin{tabular}{|c|c|}
\hline $\begin{array}{l}\text { Taşrada Farklı Kadınlık Halleri: Kadın Mali Müşavirler } \\
\text { Özelinde Bir Değerlendirme }\end{array}$ & $\begin{array}{l}\text { Different Femininities in the Province: An Analysis } \\
\text { Specific to Female Certified Public Accountants }\end{array}$ \\
\hline Öz & Abstract \\
\hline $\begin{array}{l}\text { Çalışmanın amacı Uşak'ta mali müşavirlik yapan } \\
\text { kadınların hayat anlatılarından yola çıarak taşradaki } \\
\text { farklı kadınlık hallerini, farklı iktidar ilişkisellikleri } \\
\text { açısından değerlendirmektir. Taşra gündelik hayatın dar } \\
\text { bir alana hapsolduğu, bu nedenle mikro-iktidar } \\
\text { ilişkilerinin daha hissedilir olduğu bir mekâna tekabül } \\
\text { etmektedir. Toplumsal hafıza ise mekân, grup ve zaman } \\
\text { arasındaki etkileşimin ürünüdür. Çalışma kapsamında } \\
\text { hegemonik erkeklik değerlerinin taşrada farklı } \\
\text { kadınlıkları nasıl inşa ettiği sorusundan hareketle Uşak'ta } \\
\text { mali müşavir olan beş kadınla yarı-yapılandırımış } \\
\text { derinlemesine görüşmeler yapılmıştır. Çalışma mali } \\
\text { müşavir kadınların meslekte ilerleyebilmek için erkek } \\
\text { hegemonyasının ürettiği dili benimseme yöntemini tercih } \\
\text { ettikleri sonucuna ulaşmıştır. }\end{array}$ & $\begin{array}{l}\text { The aim of this study is to analyze different feminitities } \\
\text { in the province in terms of different power relationalities } \\
\text { by focusing on the narratives of female CPAs living in } \\
\text { Uşak. The province corresponds to a space where daily } \\
\text { life is stuck in a confined space and therefore micro- } \\
\text { power relations are more tangible. Collective memory is } \\
\text { the product of the interaction among space, group and } \\
\text { time. In the study, semi-structured interviews were } \\
\text { conducted with five female CPAs in Uşak based on the } \\
\text { question of how hegemonic masculinity values build } \\
\text { different femininities in province. In conclusion, female } \\
\text { CPAs prefer the acceptance tactic for the language and } \\
\text { the space which is restricted by masculine hegemony in } \\
\text { order to progress in their careers. }\end{array}$ \\
\hline $\begin{array}{l}\text { Anahtar Kelimeler: Toplumsal Hafıza, Hegemonik } \\
\text { Erkeklik, Muhasebe Meslek Mensupları, Nitel Araştırma }\end{array}$ & $\begin{array}{l}\text { Keywords: Collective Memory, Hegemonic Masculinity, } \\
\text { Accounting Professionals, Qualitative Research }\end{array}$ \\
\hline JEL Kodları: M00, M40, Z13 & JEL Codes: M00, M40, Z13 \\
\hline \multicolumn{2}{|l|}{$\begin{array}{l}\text { Araştırma ve } \\
\text { Yayın Etiği } \\
\text { Beyanı }\end{array}$} \\
\hline Çalışmanın tamamı iki yazar birlikte/bölümleri ya & arlara paylaştırılarak oluşturulmuştur. \\
\hline Yazarlar açısından ya da üçüncü taraflar açısında & çalışmadan kaynaklı çıkar çatışması bulunmamaktadır. \\
\hline
\end{tabular}

\footnotetext{
${ }^{1}$ Dr., Uşak Üniversitesi, iiBF, Kamu Yönetimi Bölümü, sevcan.karci@usak.edu.tr

2 Dr. Öğr. Üyesi, Uşak Üniversitesi, Uygulamalı Bilimler Fakültesi, Muhasebe ve Finans Bölümü, mehtap.karakoc@usak.edu.tr
} 


\section{Giriş}

Türkiye'de muhasebe mesleği 1932 yılından itibaren yasalaşma çalışmalarına başlamış, ancak dokuzuncu girişimde yani 1989 yılında meslek yasalaşabilmiştir. 1989 yılında 3568 sayılı Serbest Muhasebeci Mali Müşavirlik ve Yeminli Mali Müşavirlik Kanunun yürürlüğe girmesiyle meslek yasal bir yapı kazanırken, o tarih itibariyle de hızlı bir odalaşma süreci başlamıştır. Böylece Türkiye'de meslek odası sistemi Türkiye Serbest Muhasebeci Mali Müşavirler ve Yeminli Mali Müşavirler Odaları Birliği (TÜRMOB) çatısı altında toplanmıştır (Güvemli, 2011: 143). 1989 yılında yürürlüğe giren bu Kanun ile meslek mensuplarına Serbest Muhasebeci, Serbest Muhasebeci Mali Müşavir (SMMM) ve Yeminli Mali Müşavir (YMM) olmak üzere üç unvan verilmiştir. Ancak 2008 yılında yapılan değişiklikle Serbest Muhasebecilik unvanı kanundan çıkartılmış, SMMM ve YMM unvanları aynı kalmıştır.

3568 sayılı Kanunda meslek mensubu olma şartları ayrıntılı bir şekilde açıklanmıştır. Buna göre SMMM olma şartları; üniversitelerin ilgili bölümlerinden en az lisans seviyesinde mezun olmak, TÜRMOB'un yapmış olduğu SMMM sınavını kazanmış olmak, en az 3 yıl staj yapmış olmak ve SMMM ruhsatına sahip olmak olarak tanımlanmıştır. Yine aynı Kanunda YMM olma şartları ise en az 10 yıl SMMM olarak çalışmak, YMM sınavını kazanmak ve YMM ruhsatını almış olmak şeklinde açıklanmıştır.

TÜRMOB verilerine göre Türkiye'de meslek mensuplarının sayısal durumları incelendiğinde kadın SMMM sayısının 33.361, erkek SMMM sayısının ise 73.149 olduğu görülmektedir. Ayrıca halen Türkiye'de 391 kadın, 6117 erkek YMM faaliyet göstermektedir. Ayrıca TÜRMOB bünyesinde hizmet veren Temel Eğitim ve Staj Merkezi (TESMER) verilerine göre yıl bazında SMMM staj başlama sınavlarına giren kadın sayısında sürekli olarak artarken, erkek sayısında sürekli bir azalma meydana geldiği görülmektedir. Bu durum mesleğe olan kadın ilgisinin artış gösterdiğini ortaya koymaktadır (Selimoğlu vd., 2020: 9). Yardımcıoğlu (2008) ABD ve Türkiye özelinde kadın meslek mensuplarının durumlarını incelediği çalışmasında, erkek meslek mensuplarının sayısal üstünlüğü olmasına rağmen yıllar içinde bu farkın açılmadığını dolayısıyla zamanla kadın meslek mensuplarının da meslekte kendilerini hissettirir konuma geleceği sonucuna ulaşmıştır. Buna karşılık Çetin (2019)'in kadın meslek mensuplarının yaşadığı sorunlara dair daha önce en çok atıf alan 35 çalışmayı incelediği çalışmasının da gösterdiği gibi meslekte hala erkek egemenliği söz konusudur. Bu çalışmanın sonucunda erkek meslek mensuplarının sayı bakımından kadınlardan fazla olduğu ortaya çıkmıştır. Ayrıca kadın meslek mensuplarının cinsiyete dayalı ayrımcılığa maruz kaldığı ve aile-iş dengesini kurmakta bazı güçlüklerle karşılaştıkları da tespit edilmiştir.

Mesleğin çatı örgütü olan TÜRMOB'un üst düzey yönetim kademelerinde görev yapan kadın sayıları incelendiğinde de sadece bir kadın üyenin bu kurullarda görev aldığı dikkat çekmektedir. TÜRMOB yönetim kurulu bir başkan, bir başkan yardımcısı, bir genel sekreter, bir genel sayman ve beş yönetim kurulu üyesi olmak üzere 9 erkek üyeden oluşmaktadır. Denetleme Kurulunda ise üç erkek üye görev yapmaktadır. TÜRMOB disiplin kurulu ise biri kadın başkan olmak üzere toplam beş kişiden oluşmaktadır. Ayrıca TÜRMOB'un ülke genelinde faaliyetlerini sürdüren SMMM ve YMM odalarının başkanları incelendiğinde tamamının erkek meslek mensuplarından oluştuğu görülmektedir. TÜRMOB'da 1990 yılından bugüne kadar görev alan 8 başkan arasında hiç kadın başkanın olmaması da konuyla ilişkili bir diğer dikkat çekici husustur. 
Türkiye'de yapılan muhasebe çalışmalarında da benzer bir durumu gözlemlemek mümkündür. Muhasebe literatüründe meslek mensupları üzerine çok sayıda çalışma yapıımış olmasına rağmen, kadın meslek mensupları üzerine yapılmış çalışmaların sayısı oldukça kısıtlıdır. Ayrıca literatürde yapılan çalışmaların büyük çoğunluğunun ampirik çalışmalardan oluştuğu, meslek mensupları üzerine nitel çalışmaların sayısının da oldukça az olduğu dikkat çekmektedir. Çalışma bu alandaki boşluğa bir yanıt oluşturmayı hedeflemektedir. Bu çalışma, Uşak'ta mali müşavirlik yapan kadınların hayat anlatılarından yola çıkarak taşradaki farklı kadınlık hallerini, farkıı iktidar ilişkisellikleri açısından değerlendirecektir. Çalışmanın amacı taşradaki farklı kadınlık deneyimlerini muhasebeci kadınların gündelik hayat pratikleri üzerinden değerlendirmektir. Çalışma kapsamında hegemonik erkeklik değerlerinin taşrada farklı kadınlıkları nasıl inşa ettiği sorusundan hareketle Uşak'ta mali müşavir olan beş kadınla yarı-yapılandırılmış derinlemesine görüşmeler yapılmıştır. Kuşkusuz ki, çalışma niteliksel bir boyut taşıdığından bulgular çalışma grubuyla sınırlıdır.

\section{Toplumsal Cinsiyet ve Mekân Arasındaki Girift ilişki: Taşranın Farklı Kadınlıkları}

Toplumsal cinsiyet sosyo-kültürel olarak belirlenen cinsiyet rolleridir, bu nedenle toplumsal düzeyde bir cinsiyet düzenine vurgu yapar. Cinsiyet sadece biyolojik temellerden değil, biyolojik cinsiyet üzerine inşa edilen ve toplumsal bağlama göre değişen bir örüntüdür (Bora, 2005: 37). Bu bağlamda cinsiyet rolleri sosyal yapılarla ve toplumsal ilişkilerle ilgilidir. Bu roller toplumsal hafıza içerisinde şekillenir. Toplumsal hafıza çalışmaları hafızanın bireysel olmadığı, toplumsal hayat içinde şekillendiği konusunda ortaklaşır ${ }^{3}$. Halbwachs'a göre toplumsal hafıza mekân, zaman ve grup arasındaki etkileşimin bir sonucudur. Halbwachs bireyin aidiyet duyduğu gruptan ayrı bir belleğe sahip olmasının mümkün olmadığını açıklar. Birey anılarını toplum içerisinde diğer insanlarla olan dolaylı ya da dolaysız ilişkileri aracılı̆̆ıyla anlar, canlandırır ve hatırlar (Halbwachs, 2016: 16). Bireysel düşüncelerimiz, anılarımız kısacası kimliğimiz "hafızanın toplumsal çerçeveleri"yle ilişkilidir. Bireysel bir hafızanın olamayacağını hafızanın kolektif olduğunu açıklayan Halbwachs bireyi toplumsal olarak şu şekilde açıklar:

"Anı, birbirine dolanmış çok sayıda kolektif düşünce zincirinin etkisiyle canlandığından ve bu düşüncelerden özel olarak hiçbirine atfedilemediğinden, bu anının bağımsız olduğunu varsayar ve anının birliğini düşüncelerin çokluğuna karşı konumlandırırız. Bu, çok ince ve birbirine dolaşmış bir miktar ip ile havada asılı tutulan bir nesnenin, kendi kendini taşıyarak boşlukta asılı durduğunu varsaymakla aynı şeydir" (Halbwachs, 1997: 95-96).

Halbwachs'ın izinden giderek bir hayat hikayesi anlatısının toplumsalla ilgili söyleyecek çok sözü olduğunu söylemek mümkündür. Gündelik hayat pratikleri ve bu pratiklerin aktarımı toplumsal hafıza içerisinde şekillenen bir anlamlandırma sürecidir. Berger toplumsal hafızanın oluşumunda yakın ilişkilerin sınırlandırıcı etkisini şu şekilde açıkıyor:

"Son olarak, özel yaşam denilen şeyi içine alan insani grup, yani kişinin ailesinden ve yakın arkadaşlarından oluşan halka da ayrıca bir kontrol sistemi oluşturur. Bunların diğer kontrol sistemlerinde olan kimi zorlayıcı formel araçlara

\footnotetext{
${ }^{3}$ Konuya ilişkin toplumsal hafıza alanında çeşitli çalışmalar için: Assmann Jan, Kültürel Bellek: Eski Kültürlerde Yazı, Hatırlama ve Politik Kimlik, Çev. Ayşe Tekin, İstanbul: Ayrıntı, 2000. Connerton Paul, Toplumlar Nasıl Anımsar, Çev. Alaeddin Şenel, İstanbul: Ayrıntı, 2000. Nora Pierre, Hafıza Mekanları, Çev. Mehmet Emin Özcan, Ankara: Dost Kitabevi, 2006.
} 
sahip olmamalarına bakarak mutlaka en zayıf halka olduklarını düşünmek büyük bir hata olacaktır. Bireyin normal olarak en önemli sosyal bağları bu halka içindedir. Buralardan gelen bir onaylanmama, prestij kaybı, kendi yakın çevresinde alaya alınma veya küçümsenme, başka yerlerden gelecek aynı tepkilere kıyasla çok daha ciddi bir psikolojik etkiye sahiptir" (Berger, 2017: 99).

Berger (2017)'in de açıkladığı gibi, kişi yakın sosyal bağları olan toplumsal grupların kontrolü altındadır. Taşra hem coğrafi sınırlar hem de sosyal bağlar anlamında bu yakınlığın hissedilir olduğu bir alan sunar. Farklı kadınlık hallerinin sosyal bağlarla hafıza içinde nasıl kurulduğu mekânla da yakından ilişkilidir. Gündelik hayatın daha yavaş aktığı taşrada, mekânın sınırlılığının zamanı da kuşattığı söylenebilir. Buna bağlı olarak taşra grubu da çerçeveleyen bir alan olarak tasvir edilebilir. Bu alanda birey en yalın haliyle bir gözetleme ve gözetlenme sarkacı üzerinde kaygan bir zeminde toplumsallaşır. Farklı kadınlıklar inşa edilirken yaşanan süreçte grubun etkisi mekânın sınırlılı̆̆ anlamında taşrada daha fazla hissedilmektedir. Bu nedenle taşra, toplumsal cinsiyet eşitsizliğinin mekân üzerinden yeniden inşasını gözlemlemek açısından canlı bir saha olarak karşımıza çıkar. Fiziksel mekân, kadın ve erkeğin günlük hayatına ilişkin somut deneyimlerin verilerini keşfedebileceğimiz önemli bir göstergedir. Toplumsal cinsiyeti bir aygıt olarak tanımlayan Butler ise bu aygıtın inşa sürecini şu şekilde açıklamaktadır:

"Toplumsal cinsiyet, tam anlamıyla insanın "olduğu ya da "sahip olduğu" şey değildir. Toplumsal cinsiyet, eril ve dişilin, toplumsal cinsiyetin varsaydığı hormonal, kromozal, ruhsal ve performatif ara formlarla birlikte üretilmesi ve normalleştirilmesinin gerçekleştirildiği aygıttır" (Butler, 2009: 75).

Cinsiyet toplumsallaşma sürecinde elde edilen bireyin de aktif olarak rol aldığı çok bileşenli bir etkileşimdir. Toplumsallaşma süreciyle ve yaşanılan mekânla da yakından ilişkilidir. Mekân ve toplumsal cinsiyet arasındaki bu ilişki, bireyin hafızasının toplumsalla yoğrulmasında da karşımıza çıkar. Assmann'ın belirttiği gibi mekânlar "belleğin saklama kapları, toplumun sosyal belleğinin üzerlerine kodlandığı elemanları" gibi bir işleve sahiptir (Assmann, 2000: 46). Cinsiyet bir performans gibi mekânda sahnelediğimiz ve kolektif hafızada canlandırdığımız bir kesişim gibi görünür. Bu kesişimin belirleyicisi olan erkek egemen toplum, kendini yaşanan bütün değişimlere rağmen yeniden kurma kabiliyetine ve bunu gerçekleştirecek araçlara sahiptir. Erkeklik çalışmalarında çı̆̆ır açan kavramıyla bütün toplumsal cinsiyet literatürünü etkilemiş olan Connell'a göre cinsiyet rejimi üzerinden şekillenen iktidar ilişkilerinin en tepesinde "hegemonik erkeklik" bulunur fakat çoklu erkeklik formları da vardır (Coles, 2009: 42). Connell hegemonik erkekliğin oluşmasında hem kurumsal iktidar ağlarının hem kültürel kodların önemine dikkat çeker. Hegemonik erkeklik sabit bir pozisyon alış değildir, toplumsal cinsiyet düzeni içinde değişen bir olgu olarak tanımlanmalıdır. Yani toplumsal hafıza içinde yeniden üretilebilir. Bu değişkenliğe rağmen Connell'a göre hegemonik erkekliğin inşasında kadınların hegemonik erkeklik düzenine verdiği onay mutlaktır. "Hegemonik erkeklik, her zaman çeşitli tabi kılınmış erkeklikler ve aynı şekilde kadınlar karşısında inşa edilir" (Connell, 1998: 183). Yani kadınların onayı olmadan bahsi geçen inşa sürecinin gerçekleşmesi mümkün değildir. Hegemonik erkeklik hem ilişkisel hem de meşrulaştırma özellikleriyle hem hegemonik olmayan erkekliklerle hem de vurgulanan kadınlıkla -yani ona itaat eden ve tabi olan ve bu yolla iktidardan pay alan kadınlık haliyle- eşit olmayan toplumsal ilişkiler üretmektedir (Messerschmidt, 2019: 60). Bahsi geçen inşa süreci toplumsal hafıza içinde gündelik hayat pratikleriyle düzenlenir. 
Gündelik hayat doğal olandır. Parçaları, bir zaman dilimde kuşkuya meydan vermeyecek bir biçimde birbirine bağlayan yapıdır. Gündelik hayat tarihten başka bir dil üretir. Görünüşte göstergesizdir fakat görünmez değildir (Lefebvre, 1998: 31). Gündelik hayatın bu zamansızlığı her alana sinmiş görünmeyen tahakküm ilişkilerinin sürdürülebilirliğinin de anahtarıdır. Sıradanlığın içine sinmiş gizem keşfedilecek stratejilerin izini verir. Eril tahakküm bu sıradanlığın içine gizlenerek zamansız, tarihsiz ve doğal olana dönüşmüştür. Toplumsal hafızanın mayalandığı mekân olarak taşranın gündelik hayat pratiklerinin içine sıkışmış sıradanlığı toplumsal cinsiyet kodlarının taşra pratikleri içinde döngüsel bir şekilde üretilmesini sağlamaktadır. Kadın ise taşra kültürünün, hafıza aktarıcısı olma rolüyle de görünür olmanın yollarını aramaktadır. Yuval Davis'in açıkladığı gibi kadın, kültürün kuşaklar arası aktarıcısı ve yuvanın kültürel kurucusu rolünü sahipleniyor; milletin kültürel yeniden üreticileri olarak kadının rolü gündelik hayatın içine siniyor (Davis, 2003: 214). Çalışma bu bağlamda farklı kadınlıklar üreten farklı iktidar görünümlerini taşradaki gündelik hayat pratiklerinden hareketle tartışmaya açacaktır.

\section{Yöntem}

Bu çalışmanın yöntemi yarı-yapılandırılmış derinlemesine görüşmedir. Kalitatif yöntem kişilerin söylemlerini, hayat hikayeleri anlatıları içinde değerlendirme imkânı verdiği için daha işlevseldir (Beaud, 1996: 234). Çalışma kapsamında Uşak'ta bağımsız olarak çalışan, kendi mali müşavirlik bürosu olan beş kadınla görüşme yapılmıştır. Görüşmecilerle ilgili detaylar Tablo 1 'de yer almaktadır.

Tablo 1: Görüşülen Mali Müşavir Kadınların Bilgilerine İlişkin Tablo

\begin{tabular}{cccc}
\hline Kodlanan İsimler & Yaş & Medeni Durumu & Görüşme Süresi \\
\hline Fatma & 45 & Evli-1 çocuk & $33 \mathrm{dk}$. \\
Ayşe & 45 & Evli- 1 çocuk & $39 \mathrm{dk}$. \\
Oya & 44 & Evli- 2 çocuk & $28 \mathrm{dk}$. \\
Harika & 30 & Evli & $35 \mathrm{dk}$. \\
Ceren & 42 & Bekar & $35 \mathrm{dk}$. \\
\hline
\end{tabular}

Görüşmelerin dördü görüşülenlerin bürolarında yapılırken, biri Uşak Mali Müşavirler Odasında yapılmıştır. Görüşülen kişilerin kimlikleri gizlenmiş ve çalışma boyunca farklı isimlerle anılmışlardır. Görüşmecilerin konuşmaları içinde geçen isimler de değiştirilmiştir. Görüşülenlerin kimliklerinin anonim kalması sağlanmış ve konuya ilişkin 08.04.2021 tarih ve 2021-67 sayılı etik kurul onay belgesi alınmıştır. Görüşülen beş kadının da kendi bürosu bulunmaktadır. Görüşülenlerin dördü evli, biri ise bekardır. Bekar olan mali müşavir görüşülen aynı zamanda meslek odasında meslek siyaseti yapmaktadır. Görüşülenlerin dördü Uşak doğumlu, biri ise Afyonludur. Uşak'ta kayıtlı 45 kadın mali müşavir bulunmaktadır. Bu kadınların çoğunluğunun kendi ofisi yoktur. Görüşmeler 12-20 Nisan 2021 tarihleri arasında yapılmıştır. Görüşmeler yaklaşık yarım saat sürmüştür. Görüşmeler deşifre edilmiş ve üç tema altında analiz edilmiştir. illk olarak kadınların çalışma hayatında yüklendikleri farklı kadınlıkların anlamları, ikinci olarak kadınların taşrada karşılaştıkları sorunlar ve son olarak kadınların gündelik hayat pratikleri kadınların hayat anlatılarından hareketle incelenmiştir. Toplumsal hafıza ve toplumsal cinsiyet kavram setlerini kullanan bu çalışmanın kalitatif yöntemi kullanmasının uygun olduğu tespit edilmiştir. Saha çalışmasına başlayan araştırmacı alana toplumsal hafızanın ürettiği dili keşfetmek için dahil olur. Araştırmacının görevi bu dili keşfetmektir. Becker, Toplumu Anlatmak kitabında grupla araştırmacı arasındaki ilişkiyi şu şekilde açıklar: 
"Sosyal bilimciler bir şeyi- bir topluluğu, bir kurumu, bir etnik grubuçalıştıklarında, olay yerine ilk gelen hiçbir zaman onlar değildir; manzaralı insansız bir yere, o yerin özelliklerini istedikleri gibi adlandırmaya ilk gidenler de hiçbir zaman onlar değildir. Bu kelimeler asla tarafsız nesnel göstergeler de değildir; aksine, bu kelimeleri kullanan insanların durumunu ve bakış açısını dile getirirler. Yerliler zaten oradadırlar; ta başından beri oradaydılar ve o bölgedeki her şeyin bir adı, çok büyük ihtimalle de birçok adı vardır" (Becker, 2016: 288).

Sahayı keşfedilmeyi bekleyen bir alan olarak tanımlayan bu çalışma Becker'ın açıkladığı bu noktadan hareket ederek taşranın farklı kadınlıkların oluşmasındaki rolünü mali müşavir kadınların anlatıları üzerinden değerlendirecektir. "Cinsiyetin toplumsallaşması sürecinde mekânın fonksiyonu nedir ve farklı kadınlıklar nasıl inşa edilir?" sorularından yola çıkarak toplumsal hafızanın mekânla ilişkisi açıklanmaya çalışılacaktır. Çalışma hegemonik erkekliğin çeperinde mevzilenen kadınlık halinin taşrada eril dili daha da güçlendiren bir işlevi olduğu iddiasındadır. Bir kadının özel alanda, kamusal alanda, anneyken, bekarken, ergenliğinde, evlendiğinde, taşrada, yaşlandığında, metropolde vb. ürettiği kadınlık halleri çeşitlilik gösterir. Kadınlıkların toplumsallığını tartışırken taşranın nasıl bir kadınlık hali ürettiği tartışmaya açılacaktır.

\subsection{Kadın Mali Müşavirler: Eril Alanda bir Varoluş Mücadelesi}

Üniversiteyi Ankara'da okuyan, Uşaklı bir erkekle evlendiği için Uşak'a yerleşen mali müşavirliğe 2000 yılında başlayan evli ve bir erkek çocuk annesi Ayşe meslek hayatında bir kadın olarak zorluk yaşamadığını açıklıyor:

"Aslında birazcık ezberlenmiş şeyler var. İşte kadın olmak çok zor, işte kadın olduğun zaman dışlanıyorsunuz gibi şeyler. Bazı meslekler için bu doğru olabilir ama ben artık gerçekten pek çok meslekte bunun aşıldığını düşünüyorum ve bu ezbere söylemlerin de insanların aslında kendi kendilerine bir duvar örmelerine neden olduğunu düşünüyorum. Ben hiçbir zaman vergi dairesine gittiğimde bir kadın olduğum için bana karşı çirkin bir tavır takındıklarını ya da erkeklerin işini yapıp benim işimi yapmadıklarını görmedim" (Ayşe, 45 yaş, evli, 1 erkek çocuk annesi).

Ayşe, kadın kimliğinin genel olarak çalışma hayatında bir sorun yaratmadığını iddia ediyor. Ofisinde görüştüğümüz Ayşe kendi mekânında kendi kimliğini güçlü bir kadın imajı üzerinden hafızasını yeniden kuruyor gibi. Ayşe'nin görüşme anında performe ettiği kimliğiyle toplumsal hafızasında deneyimlediği farklı kadınlıklar arasında bir makas olduğu söylenebilir. Mülakatın başında çalışma hayatındaki zorluklardan rahatsız olmuyor gibi görünen Ayşe'nin durumdan o kadar da memnun olmadığını görüşme sürecinde keşfediyoruz. Andan, mekândan koparılmış bir kadınlık kurgusu farklı bir roldeyken işliyor fakat gündelik hayat pratiklerinin izleri sürülürken çok saklanamıyordu. Kadın olduğu için dışlanmadığını iddia eden Ayşe meslektaşlarından "yediği mobbingi bir değersizleştirme çabası" olarak şu şekilde yorumluyor:

"Yok sayma. Yani sizi yok sayıyor karşınızdaki insanlar. Çünkü inkâr sürecinde yani bu mesleğe artık bayanlarında girdiğini, onların aktif rol oynadığını, bir gün gelip onların taht sandıkları yerden onları edeceğini inkâr etme süreçleri onların. Yok sayıyorlar. Ağız dalaşı ya da farklı bir şey değil. Mesela ne yapıyor? Değersizleştirme çalışması. Bir kuruma gidersin ya da bir yere gidersin senden önce o arkadaş gelmiştir. Orda sen varsındır, o da vardır. "Kadınlarda bu işi 
bilmiyor, yapamıyor" gibi. Değersizleştirme çalışması. Meslektaşlarımızdan daha çok mobbing yedik onu söyleyeyim".

Ayşe erkeklerin tahtlarını sarsacak "bayanların" yine aynı meslek mensupları tarafından yok sayılarak değersizleştirilmeye çalışıldığını düşünüyor. Erkek mali müşavirler, kadınların işlerini iyi yapamadıklarını söyleyerek kadınları küçük düşürmeye çalışıyor. Meslekte sayıca üstün olan erkekler hegemonyalarını güçlendirmek için eril dili pekiştiriyor. Ayşe erkek ve kadın mali müşavirler arasındaki bu mücadeleyi cinsiyetler arası bir eşitsizliğin eril dille yeniden kurulması olarak görmek yerine daha çok bu durumu piyasadaki müşteri kapma mücadelesinin bir taktiği gibi okuyor. Ağca ve Yalçın (2009) İstanbul'da faaliyet gösteren 100 kadın meslek mensubuna cinsiyete dayalı ayrımcılık bağlamında uyguladıkları anket çalışmasında da benzer bir sonuca ulaşmışlardır. Çalışmada kadın meslek mensupları özellikle mesleğin ilk yıllarında destek görmediklerini, kendilerini kabul ettirme sorunu yaşadıklarını, müşteri bulmada ve mükelleflerle olan ilişkilerinde zorluk yaşadıkları ve erkek meslektaşlarına oranla daha az gelir elde ettiklerini ifade etmişlerdir. Benzer bir örneği staj sınavını ilk girişinde birincilikle kazanan Fatma'nın anlatısında da görmek mümkün:

"Odada tabi ki bizim söz hakkımız var. Her kurulda bir kadın mali müşavirimiz var. Yönetimde, denetimde, disiplinde, delegede. Ama bunlar erkeklerin istekleriyle değil bizim baskımızla olan şeyler. Biz burada olmak zorundayız dediğimiz için olan şeyler. Ama tabii odada olunca birçok kişiyle tanışıyorsunuz. Birçok kişi oluyor. Bunların içinde buna karşı çıkanlar oluyor. Kadınlar niye var, kadınlar olmasın diyenler var. Kimileri de diyor ki daha fazla kadın olsun. Gerekçeleri; kadınlar şehir dışına seyahat edemezler, bir toplantı olduğunda ailesi ile ilgili sorun çıkar gibi bu tarz bağnaz düşüncelerle geliyorlar ama böyle bir bağnaz düşünce bizde yok. Biz bir toplantı olduğunda çok rahatlıkla gidiyoruz, geliyoruz. Hiçbir sorun yaşamıyoruz. Artık kaçıncı yüzyılda yaşıyoruz? Eşlerimiz bunlara hiçbir şey demiyor" (Fatma, evli, 1 kız çocuk annesi).

Fatma, Uşak Serbest Muhasebeci Mali Müşavirler Odası'nda artık her kurulda kadınların da olduğunu buna karşılık hala kadınların toplantılara, kurullara, gezilere katılmasıyla ilgili çekincelerinin de olduğunu anlatıyor. Bütün organizasyonlara rahatlıkla katıldığını belirtiyor fakat "eşlerimiz bunlara hiçbir şey demiyor" vurgusuyla eril dili toplumsal hafızada içeriden nasıl beslediğini fark etmiyor. Bourdieu'nun sembolik şiddet olarak adlandırdığı bu dil; sembolik şiddetin ürünü olan tahakküm yapılarıyla kurbanların, hükmedenlerin bakış açısını benimsemelerine yol açan bir yatkınlık oluşturuyor (Bourdieu, 2015: 58). Örneğin, Ayşe hem meslek hayatında kadın olmaktan kaynaklı sorun yaşamadığını hem de erkeklerin kadınları iş bilmez olarak kodlamasından duyduğu rahatsızlığı dile getiriyor. Diğer yandan Fatma meslek odasında aldığı sorumlulukları yerine getirmekte zorluk çekmediğini çünkü eşinin buna karışmadığını aktarıyor. Bourdieu'nun açıkladığına benzer bir tahakküm ilişkisi kadınların sıradan gündelik hayat pratiklerinde ve dillerinde aniden beliriyor. Benzer bir çelişkiyi Harika'nın aktardıklarında da görmek mümkün:

"Mali müşavirler arasında ikili bir ilişki var, hatta üçlü. Devlet, mükellef ve sen varsın. Buradaki sıkıntı devletle aranda olan diyalog değil. Mükellefin yapısı senin kadın olmanı anlayacak mı? Öyle insanlar hala var ülkede ne yazık ki. Mesela girmek istediğin bir ortam var oraya girsen belki de çok güzel işler alacaksın ama o ortama giremiyorsun kadın olduğun için. Mesela en basitinden sanayiye gidip mükellefinle erkeklerde olduğu kadar rahat bir şekilde diyalog 
kuramıyorsun. Yani erkekler bir çalışıyorsa, sen üç çalışıyorsun ki kendini kanıtlayabilesin. Burada öyle bir sıkıntı var" (Harika, 30 yaş, evli).

Harika erkek mali müşavirlerin çok rahat girip çıkabildikleri mekânlara bir kadın olarak giremediğinden dolayı mükellef sayısını arttırmakta sıkıntı yaşadığını dile getiriyor. Sanayi ortamına giremediğinden, erkeklerin kendi kolektif hafızalarında ürettikleri simgelere ait dili tutturamadığından dolayı mesleğinde ilerlemekte sıkıntı yaşadığını aktarıyor. Erkek egemen kamusal alanda önüne çıkan daha da eril bir alana tekabül eden sanayinin duvarlarına çarpıp geri dönerken erkeklere göre daha çok çalışmasını kendine hatırlatıyor. Eril dille olan uzlaşısını "sıkıntı devletle aranda olan diyalog değil" diyerek pekiştiriyor. Oya da erkekler arasındaki ilişkinin mükelleflerin erkek mali müşavirleri tercih etmelerinde rol oynadığını düşünüyor.

"Kurumsal firmalar için söylemiyorum. Mesela kurumsal firmaların yönetici vasıflarında da kadın sayısı çoktur ama küçük şehirlerde, küçük işletmelerle çalışıyorsanız mesela benim yaşadığım şehirde benim çalıştığım mükelleflerdeki eğitim seviyesinden dolayı ya da onların kadına bakışlarından dolayı erkek diyalogu daha önemli. Yani tabii ki size daha seviyeli davranıyorlar ve yaklaşıyorlar ama iş bir yerden sonra erkeklerle daha rahat çözülebilir hale geliyor. Yapılacak iş anlamında da şöyle; birçok yükümlülügüumüz var, tek yükümlülüğümüz Maliye Bakanlığı'na verilen gelir vergisi, KDV, stopaj değil. SSK'sı var, iş-KUR'u var, bu da gün geçtikçe artıyor. Oralara sürekli gitmek, gelmek veya çalışılan sahada sürekli işverenler seni görmek isteyebiliyorlar. Şimdi buna kadın tabi çok cevap veremiyor olabilir. Sanayiye gidip orada defter işlemeyi ya da orada ön muhasebe tutmayı ben de tercih etmiyorum açıkçası. Ben de istemiyorum. Ofisten her şeyi halletmek daha çok işinize gelir" (Oya, 44 yaş, evli, 2 kız çocuk annesi).

Sahada aktif olarak çalışmak yerine "kendi isteğiyle" işin ofis kısmında kalmayı tercih eden Oya erkekler arasında üretilen ortak dile rıza gösteriyor. Benlik sunumlarıyla dolu gündelik yaşamın sürekli yeniden düzenlenen bir formülasyona dönüşmesi muhasebecilik mesleğiyle uyumlu gözüküyor. Bu nedenle kadınlar kadın olarak meslekte özel olarak zorlukla karşılaşmalarına neden olmadığını bir çırpıda söylerken hayat anlatısı derinleştikçe kolektif hafızanın "hafıza görüntüleri" adeta çatlaklardan sızıyor. Bu nedenle egemen erkeklik değerlerinin nasıl üretildiği meselesini kadınların eril tahakkümü nasıl kabul ettikleri olgusundan ayrı düşünmek mümkün değildir. Harika bu dili şu şekilde tasvir ediyor:

"Sokak ağzı. Uşak'ın piyasasında esnaf bir adamın yanına gittiğiniz zaman sokak ağzıyla konuşabilmen lazım. İşin açığı bu. Onu da sen bir kadın olarak kendine yakıştıramadığın bazı jargonlar var burada. Sen onun içine giremiyorsun. Onların muhabbetine de giremiyorsun ama erkek bunu daha rahat yapıyor. Yani girdiğinde onun ağzıyla konuşuyor. En basiti şöyle söyleyeyim, alkollü bir ortamda oturup onları yedirip içirebiliyor. Anladını mı? Ama sen bir grup sanayiciyle ya da bir grup esnafla alkollü ortamda onların yaptığı muhabbeti yapamazsın. Adam şimdi muhasebecisiyle oturup kalkmak istiyor. Ama bunu kadınla yapamıyorlar. O yüzden seçenek olarak profesyonel düşünemedikleri için erkeği tercih ediyorlar"

Harika, çevresindeki kadın mali müşavirlerinde benzer sıkıntılarla karşılaştığını, erkeklerin "pis" ağzını kendine yediremediğini ama işin maddi boyutundan dolayı da mükellefe rest çekemediğini aktarıyor. Bu yönden meslekte kadın olarak var olmayı "yıpratıcı" olarak 
nitelendiriyor. Özçelik (2018)'in Artvin ve Rize'de faaliyet gösteren 86 meslek mensubunun toplumsal cinsiyet ayrımcılığı konusunda algılarını ölçtüğü çalışmasında da Harika'nın anlatısına benzer bir durumu gözlemlemek mümkün. Çalışma sonucunda kadın meslek mensuplarının müşteri sayısı, işyeri mülkiyeti, çalıştırdıkları eleman sayısı ve ekonomik durumlarının erkek meslektaşlarına göre daha düşük seviyede olduğu ortaya çıkmıştır. Harika da "erkek ortamlarına" giremediği için kadınların gelir kaybı yaşadığına işaret ediyor. Doğma büyüme Uşaklı olan Ceren 42 yaşında. Üniversite hayatı da Uşak'ta geçen ve 19 yıldır meslek mensubu olan Ceren 2006 yılından beri kendi ofisinde çalışıyor, bununla birlikte 2010'dan beri meslek siyasetiyle uğraştığını belirtiyor. Meslekte kadın olarak yaşadığı sıkıntıları şu şekilde anlatıyor:

"Diğer konularda ise kadın olduğumuz için biraz daha temkinli geliyorlar, işi yapıp yapmayacağımı konusunda biraz daha tedirgin oluyorlar. Onun haricinde çok büyük problemlerim olmadı. Benim tek eksi yönüm minyon tipli olmam. Minyon tipli olunca insan kapıyı çalıp girince meslektaş olarak yanımda başkalarını aradıkları oldu. (Güldü.) Müşteriye kapıyı açtığımda beni gördüklerinde mali müşavirle görüşeceğiz diyorlardı, "buyurun benim" dediğimde biraz şaşırıyorlardı. (Güldü.) Ben onun dışında bir tavırla karşılaşmadım. Ama tabii ki hep erkeklerle çalışılmaya alışılmış" (Ceren, 42 yaş, bekar).

Uşak'ta öğretmen lisesinden mezun olduktan sonra İstanbul'da iktisat eğitimi alan Harika babasının mali müşavir olan yakın bir arkadaşına özenerek öğretmenlik yerine mali müşavir olmayı tercih ettiğini anlatıyor. Matematiği çok sevdiği için bu yolu tercih eden Harika mesleğinin çok zor olduğunu fakat sürekli yenilenen mevzuat ve kanunlardan dolayı çok hareketli olan mesleğinin kendi mizacıyla örtüştüğünü de açıklıyor. Okuldaki bilgilerle mesleği yapmanın mümkün olmadığını o nedenle zaten meslek için zorunlu olan stajın yanında gerçekten işi öğretecek iyi bir mali müşavirin yanında eksikliklerin tamamlanması gerektiğini vurguluyor. Bu açığı kapatmak için piyasada sert bir mücadele olduğunun altını çiziyor. Uşak'ta ailesi aracılığıyla yakından tanıdığı ünlü bir müşavirin yanında tekrar staja başladığını şu şekilde açıklıyor.

"Ama oradan çıktıktan sonra ben beyanname bile göndermeyi bilmiyorum, 7 aylık mali müşavirim benim bir iş bulmam lazım dedim. Bu sefer de gidiyorsun piyasaya ben iş arıyorum, para vermeyin razıyım iş öğretin bana diyorsun, bu sefer de karşındaki adam sana artık sana stajyer gibi yaklaşmaya başlıyor. Sen bir mali müşavirsin. Adam sana diyor ki seçenek iki tane. Adam diye bahsediyorum çünkü genelde erkek var piyasada. iki seçenek var; ya ortak olacaksın bana toplu bir para vereceksin diyor... defterleri bölüşeceğiz gibi. ikinci seçenek olarak da seni sömürmek için alacak. Yine iş öğretmeyecek. Bu sebepten de biraz orada hinlik yaptım. $X$ abi'nin yanına gidip " $X$ abi ben bu işi yapmak istiyorum, bana kimse öğretmiyor" dedim. Ben gidiyorum herkes beni geri çeviriyor. Param da yok kimseye de ortak olamayacağım. X abi olarak bahsettiğimiz kişi senelerin mali müşaviri. O kadar kendine güveniyor ki, o kadar haklı ki güvenmekte. Bana "sen benim alıp götürsen hangi defterimi götürebileceksin ki, gel yanımda başla" dedi".

İstanbul'da staj yapmasına rağmen erkeklerle örülü piyasada kimsenin ona işi öğretmemesinden şikayetçi olan Harika zorunlu stajını bitirmesine rağmen beyanname 
yazamadığını açıklıyor. Uşak'a döndüğünde Uşak'ın ünlü mali müşavirlerden bir erkeğin yanında işi öğrenmeye başlıyor. Eril alana güçlü bir şekilde girmek için sahadaki güçlü bir erkekten destek almak zorunda kalıyor. Harika arkasındaki bu gücün çok önemli olduğunu böyle bir yola başvurmaya mecbur kaldığını da açıklıyor. Arkasındaki bu güçten dolayı piyasada kendisine diğer yeni büro açan kadınlara yaklaşıldığı gibi yaklaşılmadığını belirtiyor. Harika çalışma hayatında diğer meslektaşlarına göre daha rahat kabul görmüş. Arkasındaki erkek desteğinin bu konuda kolaylaştırıcı bir etkisi olduğunu düşünüyor. Selimoğlu vd. (2020)'nin Eskişehir'de faaliyet gösteren dört kadın muhasebeci ile görüşerek gerçekleştirdikleri nitel bir araştırmada da benzer bir durum karşımıza çıkıyor. Bu görüşmelerde kadın meslek mensuplarının, erkek meslektaşlarının müşterilere ulaşma ve sosyal ağlara dahil olma konusunda kendilerinden daha avantajlı konumda olduklarının farkında oldukları sonucuna ulaşılmıs. Harika'nın anlatısı da benzer bir duruma işaret ediyor. Kendi bürosunda erkek kardeşiyle çalışan Ceren de piyasaya girerken yanına bir erkeğin desteğini alanlardan. Ceren meslekteki yolculuğunu şu şekilde özetliyor:

"ilk başlarda biraz daha tecrübesiz oluyorsunuz, insanlara yaklaşım olarak hem kadın olarak çekiniyorsunuz. Çok samimi davransanız yanlış anlaşılabilir, çok soğuk davransanız farklı anlaşılabilir. Illk başta bu dengeyi ayarlamada sorun yaşanabiliyor. Piyasaya çıkınca gerçekten çok farklı oluyor. Esnaf ya da serbest meslek olarak vergi dairesine giderken ya da kurum kuruluşlara giderken biraz daha güven sorunumuz oluyor herhalde bizim. Bunlar zamanla size tecrübe katıyor. Yaşadıkça, gördükçe, öğrendikçe kendinize özgüveniniz artıyor. insanlara da nasıl davranmanız gerektiğini ya da her gelen mükellefe nasıl davranmanız gerektiğini zamanla yaşayarak, öğrenerek uyguluyoruz. Piyasaya çıkınca kendinizi koruya koruya bunları öğreniyorsunuz."

Ilk etapta kadın olarak kamusal alanda nasıl davranması gerektiğine dair çekinceleri olduğunu açıklarken bu durumu özgüven eksikliğiyle ilişkilendiriyor. Bunu kendi özelinde bir eksiklikmiş gibi yorumlarken "bizim" diyerek kolektif kadın hafızasına ait bir güven eksikliğine işaret ediyor. Kadına kamusal alanda nasıl davranması gerektiği, kadınlığını nasıl koruması gerektiği, içinde yaşadığı güvensiz ortamda öğretiliyor. Toplumsal hafıza; mekân, grup ve zamanın sarmalında cinsiyetlendiriliyor.

\subsection{Taşrada Farklı Kadınlık Halleri: Makbul Kadınlığın İzinde}

Görüşme yapılan beş kadın da kendi ofisleri olan ve yanlarında eleman çalıştıran mali müşavirler. Görüşmecilerden dördü mesleğe ilk bir erkek mali müşavirle çalışarak başlıyor daha sonra kendi ofislerini açıyorlar. Üniversiteyi Eskişehir'de okuyan Oya ise Uşak'a gelince hemen kendi ofisini açmış. Görüşmelerin hepsinde kadınlar mesleğin çok hızlı değişen bir yapısı olduğu için sürekli çalışmayı gerektirdiğinin altını çiziyor. Çalışma hayatında çok yoğun olmak toplumsal cinsiyet kodlarının kadına öğrettiği yemek yapan, temizlik yapan, çocuklara ve yaşlılara bakan kısacası özel alanda ev içi hizmet ve bakım işlerinden sorumlu tutulan kadının makbul kadınlık hallerinin sınırlarını zorlayan bir durum olarak karşımıza çıkıyor. Mali müşavirliğin zorluklarını Oya şu şekilde örneklendiriyor:

"Mesela evlenip çocuk yapmadan niye kadınlar için en iyi meslek öğretmenliktir lafını hiç anlamamıştım. Evlenip çocuk yaptıktan sonra anladım ne demek istediklerini. Yani kar tatilinde siz mecburen işe gelmek zorundasınız, o çocukları bir yere emanet etmek zorundasınız. Öğretmen olunca çocuklarla birlikte aynı 
anda tatil yapıp, aynı anda işe başlamış olmak rahatlıkmış. Bunu daha sonra anlıyorsunuz".

Toplumsal cinsiyet kodlarının "ideal kadın mesleği” olarak işaret ettiği öğretmenlik kadın kimliğinden dolayı meslekte sıkıntı yaşamadığını iddia eden Oya'nın anlatısına da sinmiş durumda. Benzer bir anlatıya Harika'nın yaşam öyküsünde de rastlamak mümkün:

"Ben bu mesleği seçmek istediğimde öğretmen lisesinden mezun olduğumda annemin benim üzerimde o kadar büyük baskısı vardı ki öğretmen olayım diye. Bana sürekli bu meslekle ilgili olumsuz cümleler kuruyordu. Benim o zaman sabredemediğim bir dönem olmuştu, üzerime geldiği için. Evet, öteki taraf çok basit, basitleştirmek de istemiyorum ama. Öğretmen lisesinden mezun olduğumda 24 puan veriyordu devlet. Bu da az bir şey değil. Benim Boğaziçi Üniversitesindeki bütün bölümler tutuyordu. Annem de sürekli baskı uyguluyordu. Daha sonra annemi zapt edemeyince Y Amca'nın yanına götürdüm".

Öğretmenliğin kadınlar için en uygun meslek olduğu bilgisi kuşaklar arası aktarılan kadim bir bilgi gibi her noktada karşımıza çıkıyor. Mali müşavir olmak isteyen Harika annesini ikna edebilmek için aile dostları olan bir erkek mali müşavirden destek alıyor. Makbul kadınlık kurgusu modern dünyada hafıza aktarıcıları tarafından kadınların kolektif hafızasına yeni görüntüler üzerinden adeta enjekte ediliyor. Evini ihmal etmeyen kadın, çalışan anne, çocuklarıyla kaliteli zaman geçiren ebeveynler gibi imajlar üzerinden eril tahakküm yeniden üretiliyor. Modernleşme sürecinde pozitif atıflarla örülmüş bu yeni düzende yaşlı kadınlar eski makbul bilgiyi yeni makbul bilgiyle değiştirirken aslında değişen sadece suret oluyor. Kandiyoti'nin, "ataerkil pazarlık" olarak kavramsallaştırdığı kamusal alanda saygınlık kazanmak için uyum gösterme stratejileri geliştiren farklı kadınlıklara taşrada sıkça rastlıyoruz.

"Geniş bir karşılaştırmalı perspektiften bakarak Türkiye'yi Ortadoğu'nun, Güney ve Doğu Asya'nın büyük bir bölümüyle birlikte otoriteyi, erkek soyundan devam eden geniş aile içerisinde yaşlı erkeğin elinde bulundurduğu "klasik ataerkillik"in tarihsel bölgesi içerisine yerleştirdim. Ataerkillliğin bu biçimine özgü yapısal özellikler şunlardır: Saygınlık kalıpları yaşa dayalıdır, kadınlar ve erkekler için farklı hiyerarşiler söz konusudur, cinslerin faaliyet alanları ayrışmıştır (ve hatta mekânda da ayrıştırılarak kurumsallaştırılabilir), nihayet, kadınların emeğine ve üreme kapasitelerine evlenerek dahil oldukları erkek soyu tarafından el konur" (Kandiyoti, 1996: 186).

Ataerkilliğin kendine özgü yapısı, ürettiği kalıplar sayesinde cinslerin faaliyet alanını mekânda bile ayrıştırarak kendini yeniden üretme kapasitesi gösterir. Bütün farklı hiyerarşilere göre şekillenen kadın kimliği kamusal alanda varlık gösterebilmek için eril dille bir pazarlık içindedir. Kadınlar eril dilin hegemonyasına uyum sağlamakta zorlanıyor. Taşrada bu durum yukarıda değinildiği gibi yeterince rahatsı ediciyken Uşak'ın ilçelerine gittikçe bu dil daha da sertleşiyor. Harika mekânın kolektif hafızaya sinmiş kodlarını şu şekilde açıklıyor:

"Özellikle küçük yerlerde. Mesela Uşak için söylüyorum Ulubey, Eşme o tarz yerlerde dediğimiz çok oldu. Bir iş var mesela göz göre göre başkasına gidiyor sırf erkek olduğu için. Ona bir şey yapamıyorsun çünkü sen gidemiyorsun. Mesela bunun önlemini almak istanbul'da daha kolay. Çünkü metropolde seni anlayabilecek insan daha fazla. Uşak için ne kadar daha kolaysa küçüldükçe 
daha da zorlaşıyor aslında. Daha küçük yerde ulaşamıyorsun. Sıkıntı yaratıyor. Mesela iki kadın gidelim de ilçede şunu konuşalım diyemiyorsun, illa bir erkek götürmem lazım yanımda. Biz mesela bunun muhabbetini şöyle yapmıştık bir ara danışmanlık durumları çıktı. Diyorsun ki mesela kooperatiflere, çiftçilere devletin desteklemeleri var. Bunları sen nasıl anlatabilirsin? Benim babam köyde doğmuş büyümüş, babam hayvancılık da yaptı. Ben aslında onun ağzından konuşmayı biliyorum. Ama mesela hangi köye gittiğin zaman bir amca seni ciddiye almıyor. Mesela benim bir amcayla konuşmaya gitmem gerekirse mecburen babamla gideceğim. Her ne kadar onların ağzıyla konuşabilsen de yapamazsı"

Harika mükellef arttırmak ve daha fazla iş almak için imkanların olduğunu fakat görüşmeler için daha küçük yerlere giderken alana girişte yanında bir anahtar gibi bir erkek götürmek zorunda olduğunu belirtiyor. Köylere giderken o işi kapmak için babasına başvurmayı en elverişli yol olarak görüyor. Görüşülen kadınların çoğu geleneksel kadınlık kategorilerini benimsiyor diğer yandan kendilerini geleneksel olarak tanımlamıyorlar. Özne olarak kamusal alanda aktif rol oynarken yaşam pratikleri ve söylemleri arasında muğlak daha da önemlisi kendileri tarafından kabul edilmeyen ya da farkında olunmayan bir makas var. Bahsi geçen makas bazı görüşmelerde daha görünürken bazı görüşmelerde dilin ardına gizlenmiş gibi. Köylerden, ilçelerden iş almakta erkeklere göre daha dezavantajlı olduğunu düşünen Harika'nın aksine Ayşe taşrada üretilen sosyal sermayenin mükellef edinmeyi kolaylaştırıcı bir işlevi olduğunu belirtiyor ${ }^{4}$.

"Sadece kadın olmayla ilgili belki de şöyle bir şey olabilir; yaşını gençken biraz daha imtina ediyorsunuz insanlara yaklaşırken, yeni tanıştığınızda. Çünkü özellikle küçük yerlerde kadın olmanın öyle bir dezavantajı var. Benim de Uşak dışından gelmem biraz öyle etkiledi. Kimsenin ilkokul arkadaşı değilsiniz, kimsenin liseden arkadaşı değilsiniz, kimsenin üniversiteden arkadaşı değilsiniz. Bu çok basit bir şey gibi geliyor ama işte o onun teyzesinin çocuğu, o onun düğününe gitmiş, o onun bebekliğini görmüş".

Ayşe'ye göre taşradaki yakın ilişkiler ağı mükellef sayısını arttırmaya yardımcı oluyor. Buna karşılık Ayşe küçük yerlerde yaşamanın yarattığı sosyal kontrolün kadınlar üzerinde daha etkili olduğunu belirtiyor. Diğer yandan bu baskı sosyal sermayeye dayalı bir ekonominin de oluşmasını sağlıyor. Örneğin bu durum Uşaklı erkek mali müşavir ile Uşaklı kadın mali müşavir arasında farklı bir hiyerarşi yaratırken Uşaklı olan kadın mali müşavir ve Uşaklı olmayan kadın müşavir arasında ayrı bir hiyerarşi doğuyor. Ceren ise Uşaklı olmanın mükellef sayısını arttırmakta etkili olmadığını önemli olanın mesleği icra ediş şekli olduğunu belirtiyor. Mevzuata hakimiyet Ceren'e göre kilit nokta.

"Her ne kadar Uşaklı olsanız da dışarıdan gelseniz de ilk başta işinizi düzgün yapmanız, dürüst yapmanız, daha çok ilgilenmeniz gibi durumlar zamanla sizin mükellef potansiyelinizi arttırıyor. Sıfırdan kurarken bu hususlar önemli. Düzgün ve dürüst iş yaptıkça insanlar sizi tanıyor, ona göre defterlerini siz istemeden getiriyorlar. Mesela yeni açıorsunuz sizin isminizi duyuyorlar. (...) Onun için

\footnotetext{
${ }^{4}$ Sosyal sermaye Bourdieu'ya göre üç sermaye tipinden biridir. Çevresiyle etkileşimden ve ilişkiler ağından oluşan sermayedir. Ekonomik, kültürel ve sosyal sermaye "habitus"u etkiler. Habitus, toplum içerisinde yaşamaktan kazanılmış davranış pratikleridir.
} 
babanızın ya da ailenizin Uşaklı olmasının size bir getirisi olmuyor. Ama babamın mutlaka bir iki arkadaşı gelmiştir, o şekilde olmuştur. Ama bu sebeple direkt tercih sebebi olmuyorsunuz".

Ceren mükellef sayısının artmasıyla meslekteki hakimiyet arasında yakın bir ilişki olduğunu belirtiyor. Uşaklı olmasının ofisi ilk açtığı dönemde mükelleflerin artması konusunda ona pek bir katkı sunmadığını düşünen Ceren bir defter sahibinin muhasebecisini değiştirmesinin çok zor olduğunu da ekliyor. Her ne kadar Ceren yeni mükellef kazanmakla taşrada yaşamak arasında bir ilişki olduğunu düşünmese de sorun çözücü bir muhasebecinin ününün taşrada, bir metropole göre daha hızlı ve kolay olacağını beklemek yanlış olmayacaktır.

\subsection{Gündelik Hayatın Görünmeyen Yüzü: Farklı Kadınlıkların Sınırlılıkları}

Taşrada yaşamak ve büyük bir kentte yaşamak arasında gündelik hayata ilişkin belirgin farklılıklar bulunuyor. Uşak aynı gün içerisinde birçok işin halledilebildiği bir kent. Küçük bir kent olan Uşak'ta yaşamanın gündelik hayatı kolaylaştırıcı bir etkisi olduğunu düşünen Harika İstanbul'da geçirdiği öğrencilik hayatı boyunca hep çalışmak zorunda kaldığını şu şekilde açıklıyor:

"Maddi olarak sıkıntıdaydım o yüzden çalıştım, koşturdum sadece. O yüzden buradaki yaşadığım hayatla o hayat kıyaslanamaz bile. Çünkü Uşak'ta hayat çok kolay. Sabah kalkıyorsun, yürüyerek işine gidiyorsun, çok büyük bir lüks. istanbul'da böyle şeylerin imkânı yoktu. Bir de tabii ailem burada. Karşılaştıramıyorum çünkü aynı kulvarlarda değiller. (...) Onun haricinde çalıştığım yerdeki mali müşavirim istiyordu yanında çalışmamı ama istanbul benim çok gözümü korkuttu”.

Uşak'ta doğmuş, büyümüş ve üniversite için İstanbul'a giden Harika, İstanbul'da kariyeri iyi gitmesine rağmen İstanbul'un kargaşasından ürkerek Uşak'a geri dönmüş. Uşak'ta gündelik hayatın kolaylığını bir lüks olarak değerlendiriyor. Uşak'a Ankara'dan gelen Ayşe ise taşra insanının çekingen yapısını özetliyor.

"Işsi bildiğimi de çok iyi biliyordum. O zaman Uşak'ta da ayrı işlem izin belgeleri vs. gibi konular çok korkutuyordu insanları, çok zor geliyordu. Ama ben Ankara'dan geldiğim için belki oranın havasını kokladığımdan bana da çok kolay geliyordu. Amacım kendi büromu açmaktı zaten. Çalışmaya başladığımda da zaten bunu deklare etmiştim. Sonra kendi büromu açtım".

Ankara'dan geldiği için Uşaklı meslektaşlarına zor gelen birçok işlemi çok kolay bir şekilde hallettiğini aktarıyor. Büyükşehrin karmaşa ve hızı Ayşe'ye taşrada özgüven olarak geri dönmüş. Bu katkı profesyonel hayatını olumlu etkilerken Ayşe'yi sosyal hayatının başka noktalarında zorlamış.

"Ankara'da çalışma hayatımda yaşım çok küçüktü ama orada daha rahattım. Buraya gelince taşrada olmanın bir dezavantajı var, kadına verilen bir rolü var. Ben çok rahat bir insanımdır, çok müstehcen fıkralar anlatırım mesela. (Güldü.) Severim ve keyif alırım. Burada o konuda birazcık geri planda kaldım. $O$ özelliklerimi çok fazla göstermedim. (Güldü). Çok fazla küfrederim. Babam Afyonlu mesela, bizde küfür küfür değil sıfat tamlaması gibidir. Kişinin özelliği için cümlenin başına ekleme yaparsınız. (Güldü) Çocukluğum köyde geçti, ilkokulu köyde bitirdim. Dolayısıyla onu biraz tolere ettim. Yani Ankara'da çok daha fazla yarattım. Mesela personel ilişkilerinde, müşterilerle olan ilişkilerde 
çok daha rahattım. Buraya geldiğimde birkaç sene bunları birazcık baskıladım ve dikkat ettim. Dobra kadındır derler. Her duruma uygun bir fikra anlatabilirim. (Güldü)"

Ankara'nın küfreden, müstehcen fıkralar anlatan Ayşe'si, Uşak'ın "dobra kadını"na dönüşene kadar bir süre kendini gizleme taktiğini tercih etmiş. Ayşe görüşmenin başında kadın olarak bir sorun yaşamadığını söylerken belli ki gündelik hayatında verdiği bu tavizlerle eril dilin kabullenicisine ve aktarıcısına dönüştüğünü görmezden geliyor. Müstehcen fıkralar anlatmak, küfretmek gibi toplumsal olarak kadınsı kabul edilmeyen bu pratikler ancak karşıtının dilini benimsediğinde kabul görüyor. Yenge, bacı, abla, dobra gibi kalıplara dökülmeden farklı kadınlıklar eril konuşamıyor. Taşrada kadının toplumsal konumu kimin eşi ya da kızı olduğu daha da önem kazanırken toplumsal hafızada üretilen toplumca biçilmiş rolleri benimsemek zorundadır (Eliuz, 2011: 222). Çalışma hayatında çok belirgin şikayetler sıralamayan kadınlar konu gündelik hayata gelince adeta ipuçlarını görüşmenin içine serpiştiriyor. Harika işe gelirken giydiklerinin sınırlarını mükelleflerinin çizdiğini açıklıyor.

"Bazı mükelleflerimin geleceğini bildiğim günler giyimime kuşamıma biraz özen gösteriyorum. Sanayiden geliyor mesela adam o adamın yanında mini etekle oturamıyorsun ya da dekolte bir kıyafet giyemiyorsun. Onun geleceğini bildiğim günler biraz daha özen gösteriyorsun kıyafetlerine. Özen gösteriyorsun derken şıklık anlamında bahsetmiyorum. Biraz daha usturuplu derler ya, öyle giyinmeye çalışıyorum. Söylemesi çok çirkin ama Uşak'ın erkekleri biraz aç. (Güldü.) Ne olursa olsun bir şekilde bakıyorlar. O yüzden rahatsız olmamak için özen gösterdiğimiz durumlar oluyor. Yaşımı itibarıyla, biraz küçük olduğum için beni ciddiye almaları için bazen vergi dairesine gideceğim zaman özellikle müfettişle bir işim olduğu zaman giyinip gidiyorum. Daha düzgün, daha formel giyiniyorum".

Harika gün içinde ziyaret edeceği mekâna göre bazen "özenli" bazen de daha formel giyinmeyi tercih ettiğini açıklıyor. Harika devletle karşılaşacağı zaman daha resmi, sanayici mükellefleriyle görüşeceği zaman ise daha usturuplu bir stil tercih ediyor. Özenli kıyafet vurgusu yaparken kastettiği ne güzel ne kendine yakışan ne de içinde kendini iyi hissettiği bir kıyafet. Bahsettiği kendinin de net bir şekilde söylediği gibi taşranın toplumsal hafızasının ona öğrettiği bedeniyle kurduğu ilişkinin sunum şekli sadece. Harika devletle gündelik hayatı içinde karşılaşacağı zaman nasıl bir yol tercih ettiğini şu şekilde açıklıyor:

"Devlet dairelerinde kadın olarak bir sıkıntı çok yaşamıyorsun. Çünkü esnaf ne kadar erkek yoğunlukluysa, devlet dairelerinde kadın da çok fazla. Ama orda da ya bir ağırlığın olacak, daha önceden bir vergi dairesi geçmişin olacak, daha önceden bir tanışmışlığın olacak ya da konuşkan olacaksın açıkçası işler biraz öyle yürüyor. Mesela ben şimdi gidiyorum "ablacım benim bir işim vardı" diyorum, yani ağzından giriyorum burnundan çıkıyorum bir şekilde öğreniyorsun işini hallettirmeyi devlet dairelerinde. (...) Uşak, herkes herkesi tanıyor ben bu işi burada 1 saatte hallederim. (Güldü) Çünkü burada bir şekilde araya birini sokabiliyorsun. İşini hallediyorsun. Öyle ya da böyle bir hemşerilik muhabbeti de var. Mesela giriyorsun ben Çırpıcılarlıyım, benim kocam Aktaşlı, siz de mi Aktaşlıydınız gibi. Öyle bir şekilde işini hallediyorsun. O yüzden devlet dairesi ayağında çok fazla sıkıntı çekmiyoruz. Ama erkeğin yoğun olduğu iş hayatında biraz sıkıntı yaşıyoruz evet". 
Kadın çalışanların fazla olduğu devlet dairelerinde kendini daha "ev"inde gibi hisseden Harika kadınlar arası ortak dili konuşurken kendini daha rahat hissediyor. Kendini güvende hissettiği alanda işlerini halletmesi daha kolay oluyor. Vergi dairesinde işini hemşerilik ilişkileri üzerinden hızlandıran Harika aynı ağları kurarak sanayiye girmeyi ise başaramıyor.

"Benim sanayici kuzenlerim var. Şimdi ben sanayici kuzenlerimin yanına istediğim kadar rahat girip çıkabilsem, yanındaki yöresindekiyle konuşarak muhabbete girebilirsin. Ama şimdi sanayideki kuzenim dahi beni yanına alıp da oraya götürmez. Ortam çirkin. Yarın bir gün biri bir laf eder, zaten sen de giremiyorsun. Sanayiye erkekler kadar rahat girip çıkamıyorsun. Böyle bir kötülügü var. (...) Kendime güveniyorum, yarın bir gün daha güzeli olur ama erkekler kadar kolay olmaz. Bizimki biraz daha sancilı olur. Kendini kanıtlaman lazım. Bu iş nasıl oluyor? Bir tane yeni mükellef geliyor, yeni mükellef çevrede konuşuyor, duyuluyor. Artık bizim için böyle oluyor. Bizim pazarlamamı bu şekilde oluyor ne yazık ki".

Harika devlet dairesinde kolayca kullandığı hemşerilik, akrabalık, komşuluk gibi yakın sosyal gruplara ait ağları kolayca kullanırken farklı bir mekânda bu ağlar çalışmıyor. Harika'nın anlatısı taşrada gündelik hayata ve toplumsala dair bize çok şey söylüyor. Öncelikle Harika sanayiye tek başına gidemeyeceğini zaten en baştan kabul etmiş görünüyor. Toplumsalın bu sınırını aşmak için mekânın dilini bilen bir erkeğe başvuruyor fakat bu yakın sosyal ilişki de hafızanın çerçevesinin içine dahil olma imkânı vermiyor. Berger (2017)'in de açıkladığı gibi öznenin yakın çevresinden gelen kontrol sistemi rahatlatıcı değil çoğu zaman zorlayıcı olmaktadır. Kişi yakın sosyal bağları olan grubun kontrolü altındadır. Harika, kuzeni tarafından sanayiye götürülse belki birçok mükellef elde edecek ve ekonomik olarak çok rahatlayacakken durum yine erkek hegemonyasını güçlendirecek farklı bir stratejiye doğru evriliyor. Benzer bir stratejinin ürettiği dili Ceren'in ifadelerinde de keşfetmek mümkün. Uşak'ta mali müşavirler oda yönetiminde 2016'ya kadar hiçbir kadının görev almadığını belirten ve yönetim kurulunda görev yapan Ceren bekar olmasının meslek siyasetine girmesini kolaylaştırdığını açıklıyor:

"Çünkü kurullarda görev almak bir özveride bulunmayı gerektiriyor. Belli bir zamanınızı ayırmanız gerekiyor. Şehir dışı seyahat oluyor, aileden ve sosyal hayattan zaman ayırmanız gerekiyor. Ben herhalde bekâr olunca biraz daha bu işler yürüyor. Ama tabii evliler yapamaz mı, mutlaka yapar. Ama çocuğunu bırakması gerekecek, biraz da artık kadınların bunu isteyip ön plana çıkarması gerekiyor bence. Erkeklerden beklemeden bunları yapmamı gerekiyor. Zorlukları sizi biraz daha bazı konularda geriye itmeye çalışıyorlar. Mesela erkek işle ilgili bir yere gittiğinde sizin kadın olarak gitmeniz hoş karşılanmıyor. Bu gibi şeylerle karşılaşıyoruz ne yazık ki. Mesela bir kadın meslektaş erkek olduğunu gördüğünde gelmeyebiliyor".

Bekar olduğu için evle, yemekle ve çocukla ilgili "sorumluluk"ları olmadığını açıklayan Ceren akşam olan yemeklere bu nedenle daha rahat katıldığını aktarıyor. Meslek odası kurullarında yer almak için evli kadınların kendine göre daha çok fedakârlık yapması gerektiğini de belirtiyor. Ceren "erkeklerden beklemeden" kadınların biraz daha özveri göstererek mesleğin sorunlarına yönelmesi gerektiğini açıklarken gündelik hayatında gözlemlediği bu durumun sorumluluğunu genel çerçeveyi görmeyip kadınlara yükleyen bir söylem üretiyor. Oda başkanı olan bir erkeğin kadınları da yönetimde görmek istemesi üzerine meslek siyasetinde çalışmaya başlıyor. Erkek hegemonyası içinde erkek hegemonyasının izin 
verdiği ölçüde giyimine ve diline dikkat ederek kurumsal cinsiyet rejiminin içinden bir dille kadınların fedakârlık yapmasını bekliyor. Bu durum Bourdieu'nun alanın işleyebilmesi için aynı zamanda hevesli faillerin de olması gerekliliğine dair söyledikleriyle örtüşüyor.

"Herhangi bir alanın işleyebilmesi için, söz konusu alana has belirli bir takım mücadele nesnelerinin varlığı ile oyunun ve mücadele nesnelerinin doğasına ilişkin kuralları bilen ve ikrar eden habituslarla donanmış, oyuna katılmaya ziyadesiyle hevesli faillerin varlığı gereklidir" (Bourdieu, 2016: 138).

Kendini "meslek siyaseti yapan biri" olarak tanımlayan Ceren, meslek odasında yönetim kademelerinde çalışmaya başlamış. Kadınları meslek odasının faaliyetlerine katılmaya hevesli olmamakla ve erkeklerin yolu açmasını beklemekle eleştiriyor. Bourdieu'nun yukarıda açıkladığına benzer bir dili üreten Ceren meslek odasında çalışmayan kadınlara kızıyor. Davranışlara, beğenilere, tercihlere, jestlere, mimiklere sinen habituslar bu sefer kendini dilde gösteriyor. Bu dil kadınlar arası kolektif bir hafızanın üretilmesini engelliyor. Diğer kadınlar hep erkeklerin bir şeyler yapmasını bekleyen kadınlara dönüşüyor. Bahsi geçen parçalanmışlık hali toplumsal hafızayı parçalara bölerken erkek hegemonyasının inşa edilmesini kolaylaştırıyor. Vurgulanmış kadınlığın iktidardan pay alabilmek adına ürettiği tabi olma hali cinsiyet eşitsizliğini güçlendiriyor.

\section{Sonuç}

Bu çalışmada Uşak'ta mali müşavirlik yapan beş kadının hayat anlatısı, taşrada farklı kadınlıkların nasıl şekillendiğini çözümlemek amacıyla incelenmiştir. Toplumsal cinsiyet içinde birbiriyle etkileşim içinde olan erkeklikler ve kadınlıkların farklı formasyonlarını baskı altında tutan hegemonik erkeklik Connell'ın da belirttiği gibi iktidarı elinde tutan erkeklerin toplumun geri kalanını şekillendirmesini sağlar. Kadınların, taşrada toplumsal hafızada ürettikleri dilin gündelik hayat pratiklerine yansıması şu şekilde açıklanabilir:

- Kadınların hepsi, sanayi gibi daha eril mekânlara gitmekten çekindikleri için erkek meslektaşlarından daha az bir gelir elde etmeyi kabulleniyorlar.

- Kadınların hepsi, erkek meslektaşlarının mükellefleriyle akşam yemeklerine çıkabildikleri ve alkollü ortamlara gidebildikleri için daha yakın olduklarının ve bu nedenle mükellef sayılarını arttırmakta daha avantajlı konumda olduklarının farkındalar.

- Erkeklerden destek alarak güçlenme stratejileri geliştiriyorlar. Mesleğe girişte özellikle bu destek olmadan yol almak işlerini çok zorlaştırıyor. Illerleyen yıllarda da mükellef sayısını arttırmak için bu desteğe ihtiyaçları oluyor.

Bununla birlikte kadınlar, bu durumu kabullenmiş görünüyorlar. Giyim tarzlarına ve konuşmalarına da erkeklerin şekil vermesini görmezden geliyorlar. Kadınların yoğun olarak çalıştığı devlet dairelerinde kendilerini çok daha rahat hissettiklerini dile getiriyorlar. Görüşülen kadınların çoğu sorulara direk cevap verirken bir çırpıda kadın olmaktan ötürü meslekte bir sorun yaşamadıklarını söylerken anlatıların genelinde yaşadıkları sorunlardan şikâyet ediyorlar. Bu çelişki kamusal alan ile kadın arasındaki simgesel mesafenin daha da derinleşmesine neden oluyor. Uşak'ta meslek odasında her kurulda kadınların olması kadını görünür kılmak açısından önemliyken diğer yandan kamusal alanda erkeklerle daha fazla dirsek teması halindeki kadınların, eril dille uyum göstermeleri de bir o kadar sıkıntılı görünüyor. Çünkü kadınlar uyum gösterme yöntemini taşrada gündelik hayat pratiklerini kolaylaştırmak için kullanmaktan ziyade bu uyum gösterme çabasının eril dili yeniden 
ürettiğini fark etmiyorlar. Yanında bir erkek olmadan sanayiye gitmek istemeyen Fatma, Ankara'da anlattığı müstehcen fıkraları susturan Ayşe, arkasında X Abi'si olduğu için kimsenin yaklaşamadığı Harika ve meslek odasındaki toplantılara gelmeyen kadınları eleştiren Ceren erkek hegemonyasına verdikleri onayın; sıradan, gündelik dillerindeki erilliğe sindiğini görmezden geliyorlar. Toplumsal hafızalarında kurdukları bu ortak dille farklı bir kadınlık hali üretiyorlar. Cinsiyetin bir performans gibi mekânda sahnelediğimiz ve kolektif hafızada canlandırdığımız bir kesişim olduğu doğrulanıyor. Assmann'ın belirttiği gibi taşrada mekânlar "belleğin saklama kapları, toplumun sosyal belleğinin üzerlerine kodlandığı elemanları" gibi işlevlerini yerine getiriyor. Uşak'ta kendi büroları olan yanlarında eleman çalıştıran orta-üst sınıf olarak nitelendirilebilecek görüşülen kadınlar taşrada hegemonik erkekliğin çeperinde kalarak, farklı erkeklik hallerini besleyerek cinsiyet eşitsizliklerini büyütüyor. Var olan iktidar ilişkileri içerisinde kimi zaman susarak, kimi zaman geri çekilerek, kimi zaman kabullenerek, kimi zaman ise "özenli" giyinerek kazandıkları pozisyonu kaybetmemek için taşranın sınırlarına uygun bir kadınlık kurgusu oluşturuyorlar. Hegemonik erkekliği yeniden üreten ve destekleyen bu kadınlık hali cinsiyet roller arasındaki iktidar ilişkisini dönüştürmek yerine besliyor.

"iktidar görünür olanla söylenebilir olan arasındaki ilişkiyle ilgilidir, görünürün tüketilmesini önler. Foucault iktidarın bu iki öğesini daima çatışma halinde görür. Söylenebilir olan ve görünür olan birbirlerinden ayrıdır ama yine de biri diğerinin ve koşullarının arasındaki ilişkinin içine sızar. Bu iki form arasındaki zorunlu ikili ilişki üretkendir; iktidarın negatif değil de pozitif olduğunu söylerken kastettiği şey budur" (Kendall, Gavin, 2016: 128).

iktidar ilişkilerinin bu çok katmanlı olma hali toplumsal cinsiyet hiyerarşilerini çözümlemeyi karmaşıklaştırıyor. Görünen ile söylenen arasındaki mesafeyi anlamadan bu karmaşık yapının çözümlenmesi mümkün görünmüyor. Meslekte güçlenmiş kadınlar hegemonik erkeklik değerlerine destek verdiklerini fark etmeden erkek hegemonyasını daha da görünür hale getiriyorlar. Taşranın kadınlık hallerinden sadece biri olan hegemonik erkekliğin çeperine mevzilenmiş kadınlık halini Foucault'nun da açıkladığı gibi farklı bir iktidar ilişkisine dönüştürmenin yolları aranmalı ve direniş pratikleri başkalaştırmalıdır. Bu noktada yeniden Ayşe'ye kulak vermek faydalı olacaktır. Kadın yöneticilerle çalışırken sıkıntı yaşadığı için personeliyle arasına duvarlar örmemeye çalıştığını belirten Ayşe despot bir yönetici olmadığını şu şekilde açıklıyor:

"Herkesin sorumluluğu belli, herkes zaten sorumluluğunu biliyor ve ben despot bir yönetici değilimdir. Kadınların çoğu bunu yapıyor (...) Kaynana-gelin ilişkisi gibi. Kendisi ezildiği için, o rol içerisinde farklı role geçtiği zaman karşıdakini eziyor. Çünkü farklı bir davranış biçimi bilmiyor aslında".

Stajyer bir mali müşavirin, bir şirkette çalışan muhasebecinin, bir meslek erbabının yanında işi öğrenen bir çömezin, Uşak'taki bekar bir mali müşavirin, Ankara'da okuyan bir kadın öğrencinin, evli bir kadın mali müşavirin, evli ve çocuklu ya da bekar olanın hepsinin ürettiği toplumsal hafıza görüntülerinde farklı kadınlıkların izleri bulunuyor. Bütün bu kadınlıklar toplumsal hafızada hegemonik erkeklik görüntüleriyle çerçevelenmiş birer kendi yolunu bulma hikayesi. Fakat kadınların kimi zaman görünür kimi zaman örtük olarak erkek hegemonyasından pay alma stratejileri üretmeleri erkek hegemonyasını güçlendiren bir durum olarak karşımıza çıkmaktadır. Çok bileşenli ve çok karmaşık olan bu süreç tarafların taşıdığı dönüşme ve dönüştürme kapasitelerini de kontrol altına almaktadır. Connell'ın da belirttiği gibi hegemonik erkeklik değerleri her zaman kadının onayına muhtaçtır. Bu onayı 
veren bu yolla iktidardan pay alma hakkı kazanan kadınlık hali olan "vurgulanmış kadınlık" halidir. Vurgulanmış kadınlık hegemonik erkekliğin çeperinde yer alırken eril dilin en önemli taşıyıcısı olduğunu fark etmeden güçlenir. Bu nedenle taşranın vurgulanmış kadınlık hali kolektif kadın hafızasında, kadınların üretebileceği direniş pratiklerine güç kaybettirmektedir. Ayşe kadın yönetici ve kadın çalışan arasındaki güç eşitsizliğini kaynana-gelin ilişkisine benzetirken "iktidarın görünürün tüketilmesini önleyen" fonksiyonunu sahiplenen bir role bürünmektedir. Bu çalışmanın farklı vurgulanmış kadınlık sahalarında yeniden yorumlanmasıyla kadınların dönüştürme kapasitelerini güçlendirecek yöntemler keşfedilebileceği düşünülmektedir. 


\section{Kaynakça}

Ağca, A., Yalçın, N. (2009), "Muhasebe Mesleğinde Kadın Olmak Bir Sorun Teşkil Eder mi?", Dumlupınar Üniversitesi Sosyal Bilimler Dergisi, S. 24: 37-46.

Assmann J. (2000), Kültürel Bellek: Eski Kültürlerde Yazı, Hatırlama ve Politik Kimlik, Çev. Ayşe Tekin, 1. Baskı, İstanbul: Ayrıntı.

Becker, H. S. (2016), Toplumu Anlatmak, Çev. Mesut Hazır, Şerife Geniş, Ebru Arıcan, 1. Baskı, Ankara: Heretik Yayınları.

Berger P. L. (2017), Sosyolojiye Çağrı- Hümanist Bir Perspektif, çev. Erkan Koca, Iletişim Yayınları, 1. Baskı İstanbul.

Bora, Aksu (2005). Kadınların Sınıfı: Ücretli Ev Emeği ve Kadın Öznelliğinin İnşası, İletişim Yayınları, 1. Baskı İstanbul.

Bourdieu, P. (2016), Sosyoloji Meseleleri, Çev. Aslı Sümer, Mustafa Gültekin, Filiz Öztürk, Büşra Uçar, 1. Baskı, Ankara: Heretik Yayınları.

Bourdieu, P. (2015), Eril Tahakküm, Çev. Bediz Yılmaz, 2. Baskı, Bağlam, İstanbul.

Butler, J. (2009), "Toplumsal Cinsiyet Düzenlemeleri", Cogito, Yapı Kredi Yayınları, S. 58: 73-91.

Coles, T. (2009), "Negotiating the Field of Masculinity: The Production of Multiple Dominant Masculinities, Men and Masculinities, V. 12, N. 1: 30-44.

Connell, R. W. (1998), Toplumsal Cinsiyet ve İktidar: Toplum, Kişi ve Cinsel Politika, Çev. Cem Soydemir, 1. Baskı İstanbul: Ayrıntı.

Connerton, P. (2000), Toplumlar Nasıl Anımsar, Çev. Alaeddin Şenel, 1. Baskı, İstanbul: Ayrıntı.

Çetin, A. A. (2019), "Muhasebe Mesleğinde Kadın”, (Ed. İ. Kumkale), Kadının Iş̧ Yaşamı ve Etik, Ankara: Nobel Akademik Yayıncılık, 1-19.

Davis, Y. N. (2003), Cinsiyet ve Millet, Bektaş, A. (çev.),1. Baskı Illetişim, İstanbul.

Eliuz, Ü. (2011), “Cinsel Kimlik Paniği: Kadın Olmak”, Turkish Studies, C. 6, S. 3: 221-232.

Güvemli, O. (2011), "Türkiye'de Muhasebe Meslek Örgütünün Kuruluşu ve Gelişmesi”, Muhasebe ve Finans Tarihi Araştırmaları Dergisi, C. 1: 129-145.

Halbwachs, M. (2016), Hafızanın Toplumsal Çerçeveleri, (Çev.) Büşra Uçar, 1. Baskı, Heretik, Ankara.

Halbwachs, M. (1997), La mémoire collective,6. Baskı, Albin Michel, Paris.

Kandiyoti, D. (1996), "Türk Toplumunda Erkek Egemenliğinin Çözümlenmesine Yönelik Notlar", Deniz Kandiyoti (ed.), Cariyeler, Bacılar, Yurttaşlar, çev. Şirin Tekeli, Aksu Bora vd.,1. Baskı, İstanbul: Metis.

Selimoğlu, K. S., Cengiz, A., Özdemir, A., Yalı, B., Yiğit, M. (2020), "Sayıların Görül(e)meyen Kahramanları Kadın Muhasebeciler: Eskişehir'de Keşifsel Bir Çalışma", Muhasebe ve Denetime Bakış, C. 20, S. 60: 1-18.

Kendall G., Wickham G. (2016), Foucault'nun Yöntemlerini Kullanmak, Çev. Umut Yener Kara, Turgay Sivrikaya, 1. Baskı, Islık Yayınları, ìstanbul.

Lefebvre, H. (1998), Modern Dünyada Gündelik Hayat, Gürbüz, I. (çev.) , 1. Baskı, Metis, İstanbul.

Messerschmidt, J, W. (2019), "Hegemonik Erkeklik: Formülasyon, Yeniden Formülasyon ve Genişleme", (Ed. Ç. Günay- Erkol, N. Y. Sünbüloğlu), Çev. Eleştirel Erkeklik İncelemeleri İnsiyatifi, 1. Baskı, Özyeğin Üniversitesi Yayınları, İstanbul.

Nora, P. (2006), Hafıza Mekanları, Çev. Mehmet Emin Özcan,1. Baskı, Ankara: Dost Kitabevi.

Özçelik, M. K. (2018), "Türkiye'de Muhasebe Mesleğinde Kadınların Durumu ile Ilgili Bir Alan Araştırması", (Ed. A. Gacar, Ö.E. Sucu), Case Studies in Business \& Sport Sciences, London: 7-23.

Yardımcıoğlu, M. (2008), "Muhasebe Mesleğinde Bayanların Durumu: ABD ve Türkiye Karşılaştırması", Muhasebe ve Finans Dergisi, S. 38: 147-152. 


\section{EK-1}

\section{Görüşülen mali müşavir kadınlara dair bilgiler;}

Fatma: 45 yaş. Anadolu Üniversitesi İşletme Bölümü'nden mezun. Fatma evli ve bir kız çocuğu var. Fatma'yla kendi ofisinde süren 33 dakikalık bir görüşme yapılmıştır.

Ayşe: Gazi Üniversitesi mezunu, kendi ofisi olan bir kadın mali müşavir. Ayşe 45 yaşındadır. Uşak'a evlilik sebebiyle gelen Ayşe'nin bir erkek çocuğu var. Görüşme Ayşe'nin ofisinde yapılmıştır. Görüşme 39 dakika sürmüştür.

Oya: Anadolu Üniversitesi mezunu Oya, 44 yaşındadır. Evli ve 2 kız çocuğu var. Görüşme kendi bürosunda yapılmış ve 28 dakika sürmüştür.

Harika: İstanbul Üniversitesi mezunu Harika evli, 30 yaşında. Görüşme kendi bürosunda yapılmış ve 35 dakika sürmüştür.

Ceren: Anadolu Üniversitesi mezunu olan Ceren 42 yaşında ve bekar. Görüşme Uşak'ta meslek odasında yapılmıştır. Görüşme 35 dakika sürmüştür 


\section{Extended Summary}

\section{Different Femininities in the Province: An Analysis Specific to Female Certified Public Accountants}

The present study intends to analyze different femininities in the province in terms of different power relationalities by focusing on the narratives of female CPA living in Uşak. Within the context of the study, a semi-structured interview was conducted with five female CPAs who have their own offices in Uşak based on the question of how hegemonic masculinity values build different femininities in the province. Located in the west of Turkey, Uşak is a small city with a population of 369.433 and it mostly depictures the features of the Central Anatolia Region since it is located in the hinterland of the Aegean Region. All of the five interviewed female CPAs have their own offices. Four of them are married with children whereas one of them is single. Life stories of those women were analyzed in the study. The qualitative method is more functional since it enables analyzing people's discourses within their life stories (Beaud, 1996: 234). The aim of the study is to discuss how daily life practices coded through space produce masculine language in the collective memory of the province. Within this context, the concept sets of Halbwachs and Connell were utilized. This relation between space and gender also confronts us in the kneading of an individual's memory with collective memory. According to Halbwachs, collective memory is the result of the interaction among space, time, and group. Gender is a multi-component interaction which is attained in the process of socialization and where an individual also takes a part actively in this process. On the other hand, through both relational and legalizing features, hegemonic masculinity produces social relations which is both unequal to non-hegemonic masculinity and emphasized femininity. This emphasized femininity refers to obeying and being liable to hegemonic masculinity and getting a share from the power through this way (Messerschmidt, 2019: 60). The mentioned process is organized by daily life practices in collective memory. The province corresponds to space where daily life is stuck in a confined space and therefore micro-power relations are more tangible.

Analyzing the findings of this study shortly, it can be stated that female CPAs prefer the acceptance tactic for the language and space which is restricted by masculine hegemony in order to progress in their careers. The field work tells us that masculine language is more tangible on women in the province compared to Turkish metropolises. All of the women expressed that they need to go to an industrial area to enhance the number of taxpayers, but they cannot do so and thus, they have to work more compared to their male colleagues. All of the women are of the same opinion in that they feel more comfortable when they go to public offices. Furthermore, the women convey that they are careful about how they talk and what they wear while they meet their male clients since "they do not want to be misunderstood". They explain that they do not talk very "friendly" and they are very "careful" about their dressing in order not be misunderstood. Here, the adjective "careful" refers to the meaning of no obscene dressing style rather than feeling good in a dress. The women who expect for support from the men around them (cousin, elder brother, friend, etc.) in order to go to industrial area or find an industrial taxpayer are seemed like they explain how Connell's hegemonic masculinity repressing different formations of masculinities and femininities interacting each other in social gender codes -in other saying men having the power- shapes the rest of the society. While most of the women interviewed answered the questions directly and expressed that they do not have difficulty at once, they started to complain about some problems they encounter in most of the stories as the interviews got deeper. This conflict causes more deepening in the symbolic distance between public space and woman. While the fact that there are women in each council of professional chamber of Uşak in terms of making women visible, it looks dreary that the women who are in a close contact with men more often in public space adjust to masculine language. This is because women are even not aware of this adjustment, setting aside they use it to ease their daily life practices in the province. Fatma, who does not want to go to industrial area without a male companion; Ayşe, who shuts up nasty jokes she tells in Ankara; Harika, whom nobody can approach since she is supported by elder brother $X$ and Ceren, who criticizes women who do not attend meetings in the chamber of profession ignore that the approval they give to masculine hegemony cringes on the masculinity in their ordinary and daily language. They produce a different femininity through this common language they have developed. It is affirmed that gender is an intersection which we put on a stage like a performance and picture in collective memory. As Assmann stated, spaces in the province function as "storage boxes of memory, components on which social memory of the society is coded". Considered as middle top class, the interviewed women who have their own offices and staff in Uşak grow gender inequality by feeding different masculinities and staying in the circle of hegemonic masculinity. In the present power relations, they build a femininity fiction which is appropriate for the confines of the province in order to keep their position by keeping their silence, by stepping back, by accepting or by getting dressed "carefully". Being only one of the femininities in the province, deploying in the circle of hegemonic masculinity should seek for ways to transform masculine domination strategies into a different power relation and it should transfigure resistance practices as Foucault explains.

There are all seen different femininity traces on the collective memory produced by an intern CPA, an accountant working for a company, a disciple learning the profession from an expert, a single public accountant in Uşak, a female university student in Ankara, a married female CPA, a married with children one or a single one. All of those femininities are narrations of making her own way framed with hegemonic masculinity images in collective memory. However, women's producing a strategy of taking a share from masculine hegemony in a visible or in an implicit way confronts us as a challenge which empowers masculine hegemony. This multi-component and complex process also takes each party's transformation and redefinition capacities under control. The emphasized femininity of the province makes resistance practices which can be produced by women lose power in collective women memory. If the study is tested in femininity fields emphasized differently, it may discover methods which can empower women's redefinition capacities. 